\title{
Assessing the Human Capital Emergence, Performance and Effectiveness in a Brazilian Retail Bank
}

\author{
Pedro Paulo Carbone ${ }^{1}$, Tito Belchior Silva Moreira ${ }^{2} \&$ Osvaldo Candido $^{2}$ \\ ${ }^{1}$ INTELETTO - Instituto de Análise do comportamento e desenvolvimento de competências Ltda., Brazil \\ ${ }^{2}$ Graduate Program of Economics. Catholic University of Brasilia, Brasília \\ Correspondence: Pedro Paulo Carbone, INTELETTO - Instituto de Análise do comportamento e \\ desenvolvimento de competências Ltda., Strvn, Qd. 702, Bl P, Sala 1064, Asa Norte - Brasilia/Df, Brazil. Tel: \\ 55-61-9272-9839. E-mail: carbonepp@gmail.com
}

Received: October 3, 2017

Accepted: October 25, 2017

Online Published: November 15, 2017

doi:10.5539/ijef.v9n12p134

URL: https://doi.org/10.5539/ijef.v9n12p134

\begin{abstract}
To assess the human capital (HC) effectiveness on the operational results of a major Brazilian retail bank (Bank), a HC inventory of the Bank's employees with information on 25 attributes of $\mathrm{HC}$ and six operational performance measures of the Bank in the period of 2006-2008 is used. Thus, this study relies on proven information of all the Bank's staff and not on surveys as often used in the literature. The empirical results show that the effectiveness of the $\mathrm{HC}$ is related to the establishment of an optimal construct of HC attributes and to the improvement of specific skills. Furthermore, the turnover has a negative impact in maintaining high HC employees into the branches with negative effects on the credit control process and the Bank's profitability. Lastly, the staff size into the branches as well as the economic conditions surrounding them play also an important role for the $\mathrm{HC}$ effectiveness.
\end{abstract}

Keywords: human capital performance, retail bank human capital inventory, operational results, factorial analysis, panel data models

JEL Codes: J24; M5; G2.

\section{Introduction}

The theory of the Resource-Based View (RBV) of the firm (Barney, 1996; Lippman \& Rumelt, 1982) only slightly advanced the understanding of competence and its mechanisms of development. Despite its emphasis on the company's internal resources. To overcome these shortcomings, the competence-based competition theory emerged. The theory of competence-based competition offer a relevant information for understanding the dynamics of HC formation in organizations.

The theory starts with the concept of core competence from Prahalad and Hamel (1990), which specified an organization's essential, unique, and distinctive competences that offer an intrinsic competitive advantage and are therefore key factors in differentiating a company from its competitors. The authors described essential competences as a set of skills and technologies that provide advantages for a company to compete and constitute its most valuable resource. Competence-based competition allowed an analysis of competition as a dynamic contest between competences, i.e., between competing firms (Sanchez \& Heene, 1997).

Although the theory of competence-based competition has driven companies to understand the importance of essential competences in organizations, it does not explain how learning occurs or how knowledge is created and managed. The most recent theories regarding the management of intangibles help with this understanding.

In this way, the objective of this work is to establish the human resource management (HRM) practices that are most suitable for improving the performance of the 3,603 branches of a Brazilian retail bank, the study examined the effectiveness of the Bank's human capital (HC) resources. Therefore, a HC inventory conducted on all of the Bank's employees who worked in the bank's branches during the period from 2006 to 2008 is used. At the time of the study, the Bank had 3,603 branches established in every state in Brazil and 55,550 employees in these production units.

This study examine the emergence and performance of the Bank's human capital by configuring a case study. Unlike others studies on HC, based on survyes, this paper uses proven information mined from 55,550 bank 
emplyees curricula and operating results from 3,603 brenchs of the Bank. The database includes information on twenty-three human capital characteristics, four control variables, six operational performance measures related with profitability and credit for each branch of the Bank over five semesters.

Three multivariate analysis techniques were applied to this empirical study: factorial analysis, fixed effects and random effects panel-data models, and a tobit panel-data model. The study enabled the confirmation of relevant empirical studies while offering new contributions to the literature. In particular, the study aimed to understand the relative impact of various human capital resources on corporate performance, the system of high-performance HRM practices, the impact of specific and generic competences of the Bank's performance, the set of $\mathrm{HC}$ resources most appropriate for each type of operational performance desired by the Bank, the durability of HR practices, the problem of turnover and appropriate workforce size to achieve high performance, and the impact of the external economic context on the emergence and effectiveness of the Bank's human capital. The study therefore presents objective benefits for strategic HR management for the Bank, establishes the importance of a human capital inventory for contemporary organizations, outlines the properties of corporate human capital, and identifies the study's limitations, encouraging new research in the field.

This article is divided into six sections including this introduction. The second section presents the theoretical basis of the work and the research hypothesis. The third section deals with the research method. The fourth section presents the results and their analysis. The fifth section provides a discussion of the results and the sixth presents some concluding remarks.

\section{Setting the Hypothesis}

\subsection{Management of Intangibles: Knowledge, Competency and Intellectual Capital}

Researchers have considered the knowledge incorporated into corporate human capital as belonging to the most universal resource that meets the criteria for creating a sustainable competitive advantage (Crook et al., 2011; Grant, 1991; Kogut \& Zander, 1992). Supported by the theories of the RBV and competence-based competition, several theoretical and methodological perspectives emerged to qualify knowledge as the most important production factor, especially the theories of knowledge creation (Nonaka \& Takeuchi, 1997) and learning organizations (Argyris \& Schon, 1978; Senge, 2003). Both of these theories consider knowledge an individual and social creation that is expanded by an organization through forming networks of knowledge that qualify and enrich the company's human capital. The theory of intellectual capital also stands out (Edvisson \& Malone, 1998; Kaplan \& Norton, 2004; Stewart, 1998; Sveiby; 1998). It proposed monitoring intangible assets, mainly human capital, along with management by competencies (Brandão et al., 2008; Brandão, 2009; Carbone, Brandão, Leite, \& Vilhena, 2005; Ienaga, 1998; Le Boterf, 1999; Whiddett \& Hollyforde, 1999; Zarifian, 1999), which proposed permanently mapping human capital through identifying organizational, professional (desired for functions), and personal competencies. Mapping was performed to understand the possible competency gaps for each employee or work group that may prevent the organization from reaching desired performance levels. In their own way, each of these four perspectives argue in favor of knowledge and state that knowledge is ultimately the only true source of a sustainable competitive advantage once it is incorporated by employees and appropriately shared.

A particular HR practice of the studied Bank studied can train educators of the employees of the branches to spread specific knowledge within their network of branches. Therefore, it can be argued that the Bank's branches with a higher percentage of corporate educators will have a greater ability to share knowledge internally, develop better HC, and achieve superior performance. Thus,

\section{Hypothesis 1 - The existence of corporate educators is positively correlated with the performance of the} branches.

In addition to these considerations, a focal point in this study's approach is that research on HC in companies has developed from assumptions of the classical theory of human capital. However, this understanding has only been possible based on studies of the cause-and-effect relationship between HR practices and performance. The subject of the process, HC, has often been only marginally evaluated, most likely because of the intrinsic difficulty of gathering exhaustive information from companies on their employees. Different authors (Batt, 2002; Jiang et al., 2012; Marimuthu, Arokiasamy, \& Ismail, 2009; Ramsey, Scholarios, \& Harley, 2000; Takeuchi et al., 2007; Yound \& Snell, 2004) have argued that HC is understood as a mediator between HR practices and company performance, and these authors understand that a consensus is emerging among scholars of the subject.

In proposing this hypothesis of mediation, the authors make explicit the importance of measurement mechanisms tied to the phenomenon. Nonetheless, it can be assumed that a more particular understanding of a company's HC 
phenomenon is an important condition for uncovering the most effective HRM practices. Thus,

Hypothesis 2 - Detailed knowledge about an organization's HC as well as its consequences for performance enable identification of the most and least effective HR management practices.

\subsection{Human Capital and Individual KSAOs as Isomorphic Elements}

The term HC refers to people's knowledge, skills, and attitudes (KSA) (Coff, 2002). Ployhart and Moliterno (2011) defined $\mathrm{HC}$ as a resource within the unit that is created from the emergence of knowledge, skills, attitudes, and other personal characteristics (KSAOs). KSAOs are divided into the cognitive and the non-cognitive. Cognitive KSAOs refer to those that a person "can do", and non-cognitive KSAOs are those that a person "will $d o$ " (Cronbach, 1949). It is important to note that HC resources and individual KSAOs are partially isomorphic (Ployhart \& Moliterno, 2011).

Therefore, it is important to recognize that the determinants that create $\mathrm{HC}$ resources are different from those that create KSAOs. The determinants of individual KSAOs are generic and are tied to the environment experienced by the person (Lubinski, 2000), while the determinants of $\mathrm{HC}$ resources are, by their very nature, contextual and linked to the company's needs. KSAOs are inducers of HC. For Kozlowski and Klein (2000), a phenomenon is emergent when it originates in individual cognition, emotion, and behaviors, and it is amplified by its interactions and manifests itself at the highest level as a collective phenomenon.

The emergence of $\mathrm{HC}$ is a process of assembling a valuable resource within a unit, whether it is individual or collective (Ployhart \& Moliterno, 2011). Therefore, organizations create value by assembling exceptional assets, such as HC, that are intended to achieve the desired performance and customer satisfaction. There is no other reason why the management by competencies model focuses on the competency gap, i.e., evaluates an individual's personal competency developed throughout life compared with the professional competencies needed to reach organizational goals (Ienaga, 1998). This measurement strategy helps to understand the differences between personal competencies (KSAOs) held by individuals and those needed to achieve a company's goals, ultimately aligning the employees' KSAOs and the company's HC. In this way, because the studied Bank applies the 360-degree competency assessment, it determines the competency gap for each employee.

The following hypothesis can be tested for the 360-degree competency assessment system, starting from the premise that the Bank has a measurement system that determines with a certain accuracy the approximation between an individual's KSAOs and the professional competencies desired by the company. It must be noted that according to Edwards and Ewen (1996), a 360-degree competency assessment consists of a network of professionals who register and receive feedback from different assessment sources (superiors, peers, subordinates, and customers). Thus,

Hypothesis 3 - The Bank's result in the 360-degree competency assessment is positively related to the branches' performance and ability to identify high-performance employees and teams.

\subsection{The Productive Value of Experience}

For Becker (1964) and Mincer (1958), workers are heterogeneous due to differences in useful productive capacity in the labor market. Mincer (1958) went further and introduced the notion of investing in professional experience. With this approach, the author admitted that individuals acquire new productive skills after formal education, and professional experience is an important resource for acquiring competencies. However, it is often difficult to directly observe this investment. For Cart and Toutin (1998), professional experience develops competencies at work, but the competencies are determined by the variability of the jobs or occupations performed. In this sense, variation of professional activity has a fundamental role in the process of building competencies. To measure the effect of professional experience in this study, two indicators were created: average time employed at the Bank for all of the employees from the branches, and average time in a managerial role, with the latter capturing the variability in the functions performed. Thus,

Hypothesis 4 - The experience of employees in the Bank's branches is positively related to the performance of the branches.

\subsection{Specific Competences or Generic Competences: Where Is It Better to Invest?}

The concept of path dependence suggests that the value of resources such as human capital increases as soon as it becomes idiosyncratic to resolve problems that are intrinsic to a company's competitive context (Grant, 1996; Penrose, 1959). Based on this premise, recent studies argued that the value of HC increases as it becomes more specific to the firm (Dutta, Narasimhan, \& Rajiv, 2005). Unlike the generic competence that all competitors need, 
a firm's specific competence is almost inextricably linked to the firm. Thus, it is very difficult to negotiate or change it without losing value (Chi, 1994). Conversely, when competence is naturally generic, salaries and turnover are higher because the labor market is more competitive. Thus, one can weave new hypotheses tied to the Bank's HR practices that are focused on the development of specific and generic competences.

Hypothesis 5 - The relationship between human capital and the Bank's performance is more positive for specific competences than for generic competences.

Hypothesis 6 - Regarding the ability of higher education (undergraduate and graduate) to develop generic competences: Higher education is positively related to the branches' performance.

Hypothesis 7 - Concerning the training programs developed by the Bank's Corporate University for training specific competences: The Bank's training focused on developing specific competences is positively related to the branches'performance.

Hypothesis 8 - Concerning the system of knowledge certification focused on developing specific competences at the Bank: Internal certifications of specific knowledge are positively related to branches' performance.

\subsection{Interference of Context on Human Capital Effectiveness}

The degree to which different contexts condition the creation and encourage or discard the use of HC depends largely on the specific characteristics of each locality. Thus, the determinants of $\mathrm{HC}$ resources are, by their very nature, contextual and tied to market circumstances and the needs of the company (Ployhart \& Moliterno, 2011). Dealing with the internal context Gilbert (1978), established three factors that support the full exercise of competence at work: information (feedback, directional guidance, and priorities, among others), instruments (equipment and tools, among others), and incentives (monetary or non-monetary). These factors positively or negatively contribute to the full exercise of competence at work, depending on the form of management or technology. The same reasoning can be used for the external context, although considering different categories of analysis.

However, unlike the internal context, the external context is not always manageable. In this sense, it is suspected that the economic differences between regions in Brazil where the Bank operates may interfere with the applicability of the branches' HC, making it effective in certain situations and ineffective in others. For the Bank's internal context, we start from the premise that the internal environment tends to be relatively homogenous given the institutional power of HRM policies and practices. The premise, therefore, is that the profitability of the branches also depends on the external context and that good performance can only be achieved when both conditions are met: the existence of appropriate $\mathrm{HC}$ in the branch and a favorable external economic context. Therefore,

Hypothesis 9 - The external economic context where the bank branches operate is a determinant of the effectiveness of the Bank's HC. More precisely, the impact of HC in the bank branches on the profitability of their portfolios will vary depending on specific economic contexts and considering the size and power of interference from each external context.

\section{Methods}

\subsection{Population Studied and Form of Data Collection}

Longitudinal data were used for the population of a large Brazilian bank $(\mathrm{N}=3,603)$. The study included 3,603 bank branches with a total of 55,550 employees. Only branches that showed incomplete data were excluded from the study, representing a negligible portion of the population. All of the branches studied can be considered relatively homogeneous production units with a concentration of activities in retail banking, although the Bank also has wholesale operations. The study was conducted with objective information about employees' KSAOs taken directly from the employees' personal resumes located in the Bank's database. Thus, it was not necessary to use questionnaires or determine the sample because the study was operated directly with the population of the branches and the company's employees.

Organizational performance is in essence an aggregate construct (Richard, Devinney, Yip, \& Johnson, 2009), and overall measures of firm performance may not capture the real impacts of different resources such as HC (Ray, Barney, \& Muhanna, 2004). This problem does not occur with operational indicators, which are more likely to capture the real competitive advantages created by HC (Crook et al., 2011). Because the measures of operational performance in this study capture performance in activities with a specific value for the Bank's network of branches, the implications of $\mathrm{HC}$ on performance can be seen with fewer distortions. The dependent variables used, listed below, were measured from an internal operational indicator that compared performance between the 
branches on a scale from 0 to 60 . The lower limit " 0 " means a null standard of performance, while the upper limit " 60 " establishes the highest expected performance level for a bank branch. Thus, the dependent variables include 1) profitability of client portfolios (profitability) - this variable for operational performance measures the expected return on operations with clients; and 2) dependent variables in the credit process, here also called credit performance variables, namely: a) Individual timely payments - payment of financial commitments by the Bank's individual clients before the due date; b) Corporate timely payments - payment of financial commitments by the Bank's corporate customers before the due date; c) Credit limit and record - percentage of failures in preparing the records or granting credit limits; d) Loans contracted - volume of operations without operational risks that may affect the loans contracted; e) Advances to depositors - form of special lending to cover for checking account overdrafts.

Independent variables - 23 independent variables, called here $\mathrm{HC}$ resources or $\mathrm{HC}$ variables, were collected for the study. Four of the independent variables measure the level of higher education (undergraduate, MBA in corporate finance, MBA in management, Master's and $\mathrm{PhD}$ ), two measure professional experience (years at the Bank and years in a managerial role), six measure competencies (customer service, finance, internal processes, social responsibility, behavioral, and managerial), six measure certifications of specific knowledge (credit, management, agribusiness, finance, marketing, and internal controls), three measure specific training (financial investment, credit and finance analysis, and marketing and customer service), and two measure corporate educator (educator employees and educator managers). The structuring of the database for human capital considered the measurable dimensions of human competence at work, or the KSAOs - knowledge, skills, abilities, and other characteristics (Ployhart \& Moliterno, 2011). For the dimension knowledge, the independent variables higher education, specific training, and certification of specific knowledge were chosen; for the dimension skills and abilities, the variables professional experience and competencies were used; and for the dimension other characteristics, the variable corporate educator was employed. It is important to note that the variable higher education is linked with the development of generic competences of employees, and the variable corporate educator develops both generic and specific competences. The other independent variables listed above are tied to the specific competences of employees.

Control variables - By focusing on a specific production process that is replicated in thousands of the Bank's branches and is based on universal and standardized indicators, this study eliminates most sources of heterogeneity in productivity or performance between the production units. Nevertheless, one cannot say that the production lines are absolutely identical, mostly because the contexts and customer bases change. To control for the sources of variation in performance, the variables that would most impact the performance of a large network of bank branches in Brazil were chosen. It is known that a firm's size and environment may influence its performance (Keats \& Hitt, 1988; Razin, 1998, 1999; Skaggs \& Youndt, 2004). To control for the effects of size, a continuous control variable was introduced that represents the number of individuals employed in each bank branch (Huselid, 1993; Normann, 1984). A control variable was also used that controls for the economic environment of the banking industry by including a dummy for the branches' economic level. This dummy takes into account the economic indicators of the local economy and the customer base to classify the branches. To control for the economic environment, we also used a dummy for locality because the banking operations in a country such as Brazil may be impacted by the region where the branch is located. This control variable shows whether the branch is located in a metropolitan area or in a non-metropolitan city. Last, the continuous variable turnover was used because excessive movement of employees could occasionally hinder certain operations and the retention of good customers (Huselid, 1995). The control variables used include the following: Workforce this continuous variable reflects the number of employees in each branch. The number of employees is directly related to the budget, volume of operations, number of clients, characteristics of the work process, and the economic potential of the locality where the branch is located. Level of branch - this discrete variable depicts the classification of the branch adopted by the bank. It considers different economic and market factors such as the economic potential of the locality, the municipality's GDP, the historic results of the unit, the population, the number of clients, and the highest selling products at the branch, as well as the volumes of loans and borrowing. This variable is based on a scale with five levels, from 1 to 5. The branches classified at Level 1 are the most promising in terms of local economic potential. At the opposite end of the scale, branches at Level 5 have the lowest local economic potential. The frequency distribution of this variable is as follows: 411 branches at Level 1, 612 at Level 2, 1,276 at Level 3, 963 at Level 4, and 341 at Level 5, totaling 3,603 branches. Locality where branch is established - this dichotomous variable ( 0 or 1$)$ indicates the locality where the branch is established, whether in a metropolitan region (1) or a non-metropolitan region (0). Per region, the branches are distributed as follows: 847 metropolitan and 2,756 from no-metropolitan areas, totaling 3,603 branches. Turnover - this continuous variable indicates the percentage of movement of employees during the periods studied, resulting 
from internal transfers between the branches, hiring, or firing.

\subsection{HR Management Practices of the Bank and Database Specifications}

The Bank mainly uses seven HRM practices implemented between 1960 and 2005, as described in Table 1. The third column includes the HC resources tied to each HR practice. The fifth column relates the hypotheses studied in this study to the existing HR practices. The question of the relative effectiveness of the HR practices and HC resources, shown in Table 1, will be discussed later in the paper.

Table 1. Relative effectiveness of HR management practices in the bank studied

\begin{tabular}{|c|c|c|c|c|c|}
\hline $\begin{array}{l}\text { HR Management } \\
\text { Practices in the Bank }\end{array}$ & $\begin{array}{c}\text { Year when HR } \\
\text { practice was } \\
\text { implemented }\end{array}$ & $\begin{array}{c}\text { Related human capital } \\
\text { resources (independent } \\
\text { variables) } \\
\end{array}$ & $\begin{array}{c}\text { Index of effectiveness of } \\
\text { human capital resources } \\
\text { on performance }^{\mathrm{a}}\end{array}$ & $\begin{array}{c}\text { Related } \\
\text { research } \\
\text { hypotheses }\end{array}$ & $\begin{array}{c}\text { Relative } \\
\text { effectiveness of } \\
\text { HR practices }^{\text {b }}\end{array}$ \\
\hline $\begin{array}{l}\text { 1. Internal system for } \\
\text { certification of specific } \\
\text { knowledge }^{c}\end{array}$ & 2005 & $\begin{array}{c}\text { Certification of specific } \\
\text { knowledge }\end{array}$ & $100 \%$ & $\begin{array}{c}\text { Hypothesis } \\
9\end{array}$ & Very effective \\
\hline $\begin{array}{c}\text { 2. 360-degree } \\
\text { competency assessment } \\
\text { system }\end{array}$ & 2004 & Specific competences & $83 \%$ & $\begin{array}{c}\text { Hypothesis } \\
4\end{array}$ & Very effective \\
\hline $\begin{array}{c}\text { 3. Professional } \\
\text { advancement based on } \\
\text { merit }^{\mathrm{d}}\end{array}$ & 2005 & $\begin{array}{l}\text { Specific competences, } \\
\text { certification of specific } \\
\text { knowledge, and } \\
\text { experience }\end{array}$ & $\begin{array}{l}\text { Competencies }(83 \%) \text {; } \\
\text { certifications }(100 \%) ; \\
\text { experience }(50 \%)\end{array}$ & $\begin{array}{c}\text { Hypotheses } \\
4,5 \text {, and } 9\end{array}$ & Very effective \\
\hline $\begin{array}{l}\text { 4. Variable remuneration } \\
\text { based on certifications } \\
\text { of specific knowledge } \\
\text { and performance }\end{array}$ & 2005 & $\begin{array}{c}\text { Certification of specific } \\
\text { knowledge }\end{array}$ & $83 \%$ & $\begin{array}{c}\text { Hypothesis } \\
9\end{array}$ & Very effective \\
\hline $\begin{array}{l}\text { 5. Training to develop } \\
\text { specific competences }\end{array}$ & 1960 & Specific trainings & $50 \%$ & $\begin{array}{c}\text { Hypotheses } \\
6 \text { and } 8\end{array}$ & Effective \\
\hline $\begin{array}{l}\text { 6. Development of } \\
\text { generic competences } \\
\text { through incentives for } \\
\text { higher education }\end{array}$ & 1990 & Higher education & $50 \%$ & $\begin{array}{c}\text { Hypothesis } \\
7\end{array}$ & Effective \\
\hline $\begin{array}{l}\text { 7. Sharing knowledge } \\
\text { through corporate } \\
\text { educators }\end{array}$ & 1960 & Corporate educator & $40 \%$ & $\begin{array}{c}\text { Hypothesis } \\
2\end{array}$ & Little effective \\
\hline
\end{tabular}

Note. ${ }^{\text {a }}$ Measured by the percentage of positive impact of the $\mathrm{HC}$ resource on the set of dependent variables, taken from the last row of Table 3 . b The author's scale of relative effectiveness is arbitrary and considered: very effective above 80 percent; effective between 50 and 80 percent; and little effective between 20 and 49 percent. The HR practices 1 to 6 are therefore a system of high-performance HR practices. ${ }^{c}$ From 2006 to 2008, most of the Bank's employees were trained and took exams for certification of specific knowledge offered by the Bank. The program, which certified approximately 60,000 employees, charted the cognitive domain of the employees in the specific competences need for the work. ${ }^{\mathrm{d}}$ Merit, in the Bank studied, signifies meeting the requirements for competencies, certifications, experience, and job performance.

To develop this study, four databases were used for the HC variables (independent variables), control variables, and operational performance variables (dependent variables), separated by the periods available (up to five semesters) and the number of $\mathrm{HC}$ variables used, as shown in Table 2.

Table 2. Databases

\begin{tabular}{|c|c|c|c|c|c|}
\hline Database by dependent variable & $\begin{array}{l}\text { Number of } \\
\text { branches }\end{array}$ & $\begin{array}{l}\text { Number of } \\
\text { employees }\end{array}$ & $\begin{array}{c}\text { Number of observations } \\
\text { (branches X semesters) }\end{array}$ & Semesters & $\begin{array}{l}\text { Number of } \\
\text { HC variables }\end{array}$ \\
\hline $\begin{array}{l}\text { Database } 1 \\
\text { - Advances to depositors }\end{array}$ & 3,603 & 55,502 & 10,809 & $\begin{array}{l}\text { Three }\left(2^{\text {nd }} \mathrm{sem} / 2007\right. \\
\left.\text { to } 2^{\text {nd }} \mathrm{sem} / 2008\right)\end{array}$ & 19 \\
\hline $\begin{array}{l}\text { Database } 2 \\
\text { - Credit limit record } \\
\text { - Loans contracted }\end{array}$ & 3,598 & 55,195 & 14,392 & $\begin{array}{c}\text { Four }\left(1^{\text {st }} \mathrm{sem} / 2007 \text { to }\right. \\
\left.2^{\text {nd }} \mathrm{sem} / 2008\right)\end{array}$ & 19 \\
\hline $\begin{array}{l}\text { Database } 3 \\
\text { - Individual timely payments } \\
\text { - Corporate timely payments }\end{array}$ & 3,590 & 55,550 & 17,950 & $\begin{array}{l}\text { Five }\left(2^{\text {nd }} \mathrm{sem} / 2006 \text { to }\right. \\
\left.2^{\text {nd }} \mathrm{sem} / 2008\right)\end{array}$ & 19 \\
\hline $\begin{array}{l}\text { Database } 4 \\
\text { - Profitability of client portfolios }\end{array}$ & 3,598 & 55,195 & 14,392 & $\begin{array}{l}\text { Four }\left(1^{\text {st }} \mathrm{sem} / 2007 \text { to }\right. \\
\left.2^{\text {nd }} \mathrm{sem} / 2008\right)\end{array}$ & 20 \\
\hline
\end{tabular}


The fluctuation in the number of $\mathrm{HC}$ variables in the panel regressions for each dimension of operational performance is explained by the natural link between the measure of performance and the HC variable. For example, it would be unreasonable to link the $\mathrm{HC}$ variable training in marketing to the variables for credit performance. In that case, the HC variable training in marketing was tied to training in credit and finance.

\subsection{Data Treatment: Factorial Analysis}

This study includes $23 \mathrm{HC}$ variables, a number that is difficult to fit for regression models. Many HC variables in this study showed strong correlations with each other and more specifically with related variables. There were four factorial analyses performed in this study; each was associated with a database related to a specific operational performance variable (dependent variable). This procedure was necessary because the databases showed differences in the number of periods, amount of branches, and number of related human capital variables, as shown in Table 2. In three of the four factorial analyses, five factors were found: 1. Formal education, 2. Experience/training, 3. Certification, 4. Corporate educator, and 5. Competencies. In the factorial analysis for the database profitability, the same four factors were found except for corporate educator. A factor extraction was performed through the principal component analysis and varimax rotation methods, adopting 0.30 as the minimal factor loading in absolute value. The data were suitable for applying factorial analysis because a KMO (kaiser-Meyer-Olkin) above 0.82 was observed, and Bartlett's null hypothesis was rejected, indicating good fit. In three of the factorial analyses, the extracted factors accounted for 68.90 percent of the variance, and the extracted factors accounted for 58.60 percent of the variance in the other factorial analysis, meeting the requirements satisfactorily. The factors extracted from the factorial analysis did not show correlations with each other, thus avoiding the problem of multicollinearity.

\subsection{Panel Regression Model: Tobit Regression}

The data analyzed in this article refer to a period of up to five semesters. The statistical methods suitable for this dataset are panel regression models with fixed or random effects. Because the dependent variables are censored in the lower and upper limits, meaning that they are limited to a range of 0 to 60 , we can say that the choice of the tobit model is suitable for this study. The essence of the tobit model is similar to least squares regressions, but it assumes a normal truncated or censored distribution. It is therefore an effective method to estimate the relationship between a truncated or censored dependent variable and other independent variables (Amemiya, 1984). According to Greene (2003), the tobit model can be defined by the expression $y_{i}{ }^{*}=\beta^{\prime} x_{i}+\mathcal{E}_{i}$, where $\mathcal{E}_{i}$ is a random error in the equation, $\beta$ is the parameter vector and represents the coefficients to be estimated, $x_{i}$ represents the explanatory variables, and $y_{i}{ }^{*}$ is the estimated dependent variable. The variable $y_{i}{ }^{*}$ that is actually observed, i.e., the effectiveness score generated, is defined as follows for this study:

$$
\text { if } y_{L}<y_{i}^{*}<y_{U}, y_{i}=y_{i}^{*} \text {, if } y_{i}{ }^{*} \leq y_{L}, y_{i}=y_{L} \text { and if } y_{i}{ }^{*} \geq y_{U}, y_{i}=y_{U}
$$

Where $y_{L}=0$ is the lower limit, and $y_{U}=60$ is the upper limit.

The use of the Ordinary Least Squares Method to estimate the parameters of a regression with a censored dependent variable would create biased estimates. In this case, estimating the parameters is generally performed through Maximum Likelihood (Wooldridge, 2002).

The general model to be estimated is:

$$
Y_{i t}=a_{i} \sum \beta_{i} F_{i t}+\sum \lambda_{i} F_{i t}^{2}+\sum \psi_{i} X_{i t}+u_{i t}
$$

where $i=1,2, \ldots, n$ branches (production units), $t=$ periods (second semester of 2006 to second semester of 2008), $\alpha_{\mathrm{i}}=$ intercept, $Y=$ dependent variable, $F=\mathrm{HC}$ factor (independent variable), $F^{2}=$ HC factor squared, $X$ $=$ control variable, $\beta, \lambda$ and $\psi=$ parameter vectors and coefficients to be estimated, and $u_{i}=$ error term.

The independent variables for human capital were squared and regressed together with the variables in levels to capture eventual non-linear curves for the relationship between human capital and the outcome. HC variables were also regressed cubically; the results were not significant.

Although the regression model best suited for the characteristics of the data in this study is the tobit model due to the censored data for the dependent variables, this study chose to analyze the results using the three applicable regression models: fixed effects, random effects, and random effects tobit. In general, the comparison between the regression models shows that the models with random effects, fixed effects and the random effects tobit show practically identical results. The estimates were made using Stata 12 software. All of the estimates for standard errors are robust, i.e., corrected for both heteroscedasticity and autocorrelation using the Newey-West method for regressions with fixed and random effects, while correction was made via bootstrap according to Wooldridge (2002) for the random effects tobit model. 


\section{Results and Hypothesis Check}

\subsection{Results of the Panel Regressions}

The results of the regressions are explained from the relationship curves found between the dependent variables (operational performance measures) and the independent variables (human capital variables). For this purpose, the human capital variables were regressed in level and squared form, which enabled an observation of four types of relationships: 1) positive linear relationship, which means that if there is an investment in the HC resource, performance improves linearly and positively; 2) non-linear relationship, which means that there are maximum and minimum points. When the non-linear relationship shows a maximum point, it is possible to maximize performance if there are adequate increases in the $\mathrm{HC}$ resource. Conversely, when the non-linear relationship shows a minimal point, it is assumed that there is a minimum amount of the HC resource beyond which there is a positive relationship between the resource and performance. 3) Negative linear relationship, which signifies that if there is an increase in the $\mathrm{HC}$ resource, performance worsens; and 4) null relationship, or there is no statistically significant relationship.

Because the volume of regressions in this study is large, summary tables that aggregate the results from the regressions are used to present the data.

Table 3 summarizes the results of the random effects tobit regressions between human capital and profitability and between human capital and credit process for all of the Bank's branches. Each cell in Table 3 depicts the four types of relationships between the dependent variables (operational performance) and independent variables (HC) already mentioned: linear positive relationship, marked in the table by a black fill; non-linear relationship, marked by a gray fill; negative linear relationship, marked by a fill with horizontal lines; and the null relationship, outlined by the color white, meaning that there was no statistically significant relationship. The same procedure is used for the summary Tables 4, 5, and 6 .

Table 3. Summary of the results of the tobit regressions in the relationships between human capital and the dependent variables, in order of relative impact

\begin{tabular}{|c|c|c|c|c|c|c|c|}
\hline HC/Dependent variable & Certification & Competency & $\begin{array}{c}\text { Formal } \\
\text { Education }\end{array}$ & $\begin{array}{l}\text { Experience/ } \\
\text { Training }\end{array}$ & & Turnover & Workforce \\
\hline Profitability & & & & & \multirow{4}{*}{ Corporate educator } & & \\
\hline $\begin{array}{l}\mathrm{HC} / \text { Dependent variables for } \\
\text { credit process }\end{array}$ & Certification & Competency & $\begin{array}{c}\text { Formal } \\
\text { Education }\end{array}$ & $\begin{array}{l}\text { Experience/T } \\
\text { raining }\end{array}$ & & \multirow[t]{3}{*}{ Turnover } & Workforce \\
\hline Corporate timely payments & & & & & & & \\
\hline Individual timely payments & & & & & & & \\
\hline Advances to depositors & & & & & & & \\
\hline Credit limit record & & & & & & & \\
\hline Loans contracted & & & & & & & \\
\hline $\begin{array}{l}\text { Type of related competence } \\
\text { Index of effectiveness or } \\
\text { relative impact }{ }^{\mathrm{a}}\end{array}$ & $\begin{array}{l}\text { Specific } \\
\text { In } 100 \% \text { of } \\
\text { the variables }\end{array}$ & $\begin{array}{l}\text { Specific } \\
\text { In } 83 \% \text { of the } \\
\text { variables }\end{array}$ & $\begin{array}{l}\quad \text { Generic } \\
\text { In } 50 \% \text { of the } \\
\text { variables }\end{array}$ & $\begin{array}{c}\text { Specific } \\
\text { In } 50 \% \text { of the } \\
\text { variables }\end{array}$ & $\begin{array}{l}\text { Specific and generic } \\
\text { In } 40 \% \text { of the } \\
\text { variables }\end{array}$ & & \\
\hline
\end{tabular}

${ }^{\mathrm{a}}$ Form of calculating the index of effectiveness: (number of positive linear relationships + non-linear relationships) / total number of relationships.

Positive linear relationship. If there was an investment in the human capital resource indicated, performance improved.

Non-linear relationship. May have a maximum or minimum point of human capital. The relationship indicates that one can manage the optimal investments in the branch's human capital.

Negative linear relationship. If there is an investment in the human capital resource indicated, performance worsened.

Null relationship, no significance.

As shown in Table 3, it can be concluded that the Bank's HC resources positively impact most of the operational performance measures, especially the $\mathrm{HC}$ variables competency and certification, which have a positive linear relationship with most of the dependent variables studied. Experience/training has a positive linear impact on a very important dependent variable, profitability, in addition to a non-linear relationship with corporate timely payments and advances to depositors. Regarding the impact of the experience/training resource on individual timely payments, the result is linear and negative, which indicates that improvements in this HC resource may increase individual defaults. This negative relationship, unlike what was shown in the hypothesis, may have occurred because the performance levels for individual timely payments have a direct relationship with the 
particular experience of employees in the branch with individual client portfolios. This experience may be decreasing because of the greater rate of employee turnover observed with this type of client portfolio, as shown in Table 6 below. The experience indicator used in this study is an aggregate indicator that is non-specific for each process, hence its negative impact on individual loans. To reduce this effect, it might be appropriate to inhibit the turnover of individual client portfolios, thereby preserving employees' experience and specific competences in this work process as much as possible. Formal education, in turn, is a reasonable HC variable, showing a positive linear impact on the dependent variable corporate timely payments and a non-linear relationship with profitability and advances to depositors. Formal education does not seem to have an effect on the other operational performance variables. Corporate educator does not appear to be a strong HC resource because it positively impacts only two operational performance variables (advances to depositors and credit limit record).

The last row of Table 3 shows that the index of relative effectiveness of the HC resources certification, competencies, formal education, and experience/training is significant, ranging from 50 to 100 percent. This result appears to indicate that these resources are effective at generating good performance levels. Thus, Hypotheses 3, 4, 5, 7, and 8 can be accepted. It should be noted that the resource certification of knowledge is a new HR practice that is focused on the service industry, and it appears to be promising and revealing. Similar to the competencies variable, the data show that certification of knowledge is an HC variable that has a positive linear impact on half of the dependent variables in the study and a non-linear relationship with the remaining variables. Certification of knowledge is therefore projected to be a new high-performance HR practice for the service industry. Hypothesis 1 - The existence of corporate educators is positively correlated to the operational performance of the branches - is partially confirmed. The isolated positive impact of this HC variable in only two of the operational performance measures analyzed (advances to depositors and credit limit record), according to Table 3, is not sufficient to fully accept the hypothesis. Similarly, Hypothesis 6 - The relationship between HC and the Bank's performance is more positive for specific competences than for generic competences - is confirmed. The human capital resources tied to specific competences (certification, competency, and experience/training) are more effective than those tied to generic competences (formal education) in increasing operational performance (see the last two rows of Table 3). On average, there is a positive linear relationship, or at least a non-linear relationship, between specific competences and the dependent variables in 77 percent of the variables, allowing for the optimization of operational performance. Generic competences, in turn, show a lower percentage of positive linear and non-linear relationships, at approximately 50 percent. Therefore, Hypothesis 6 can be accepted. Hypothesis 2 - Detailed knowledge about an organization's human capital as well as its consequences for performance enable an identification of the most and least effective HR management practices - can be accepted as a natural consequence of the hypotheses tests conducted in this study on the effectiveness of the Bank's HC. Now that it is known which hypotheses could be accepted, it is possible to infer the Bank's most and least effective HR management practices to obtain optimal levels of operational performance. The last column in Table 1 seeks to portray the relative effectiveness of each of the Bank's HR practices. Therefore, it can be said that HR practices 1 to 6 , listed in Table 1, compose a system of high-performance HR practices, meaning an internal incentive system that creates effective corporate HC.

Hypothesis 9 refers to the interference of external context in the relationship between human capital and operational performance. In this hypothesis, the important question is whether the external economic contexts where the bank branches operate are a determinant factor in the effectiveness of HC. For this analysis, the operational performance variables were separated by the level of sensitivity to the external context. Based on their characteristics, profitability was chosen as the variable that is most susceptible to local economic power. It is assumed that in consolidated economic regions with high economic potential and purchasing power, the $\mathrm{HC}$ in branches will be more effective, creating higher profitability than the same HC located in regions with less economic power. If this hypothesis is confirmed by segregating the regressions based on the economic levels of the regions where the branches are located, it will be possible to demonstrate the phenomenon if there is a progressive decrease in $\mathrm{HC}$ effectiveness when the regressions turn to economically unfavorable regions.

Therefore, as explained above, the population of the branches was divided into seven economic clusters that translate to the economic potential of the regions where the branches are located. The tobit panel regressions between human capital and profitability were run separately according to the branch's cluster by considering the entire population of the branches within the cluster. If this line of reasoning is correct, human capital better explains the operational performance achieved in the metropolitan branches and the branches classified as Level 1 , which are regions with high economic power. Conversely, in the branches in regions classified as Levels 4 and 5 , with low economic power, human capital would not adequately explain the performances achieved. The 
results mostly confirm this hypothesis, both in the regressions based on the tobit panel model which is considered the most appropriate for the data in this study, and in the fixed effects panel model. As observed in Table 4, human capital better explains the levels of profitability reached by the metropolitan and Level 1 branches than the profitability obtained by branches in Levels 4 and 5. Table 4 summarizes the tobit regressions, showing the influence of the effectiveness of $\mathrm{HC}$ variables on profitability by branch level. Table 4 is designed to allow a comparison of the results from the tobit panel and fixed effects panel regressions. Through the color filling of the cells in Table 4, the concentration of the colors gray and black on the left side and the color white and the fill with horizontal lines on the right side is evident, confirming the phenomenon that human capital explains the operational performance of branches with high economic potential and does not adequately explain the performance for those branches with low economic potential. Thus, based on the results found for the external context, Hypothesis 9 can be accepted.

Table 4. Summary of the results of the tobit and fixed effects regressions, by branches level, in the relationships between human capital and profitability

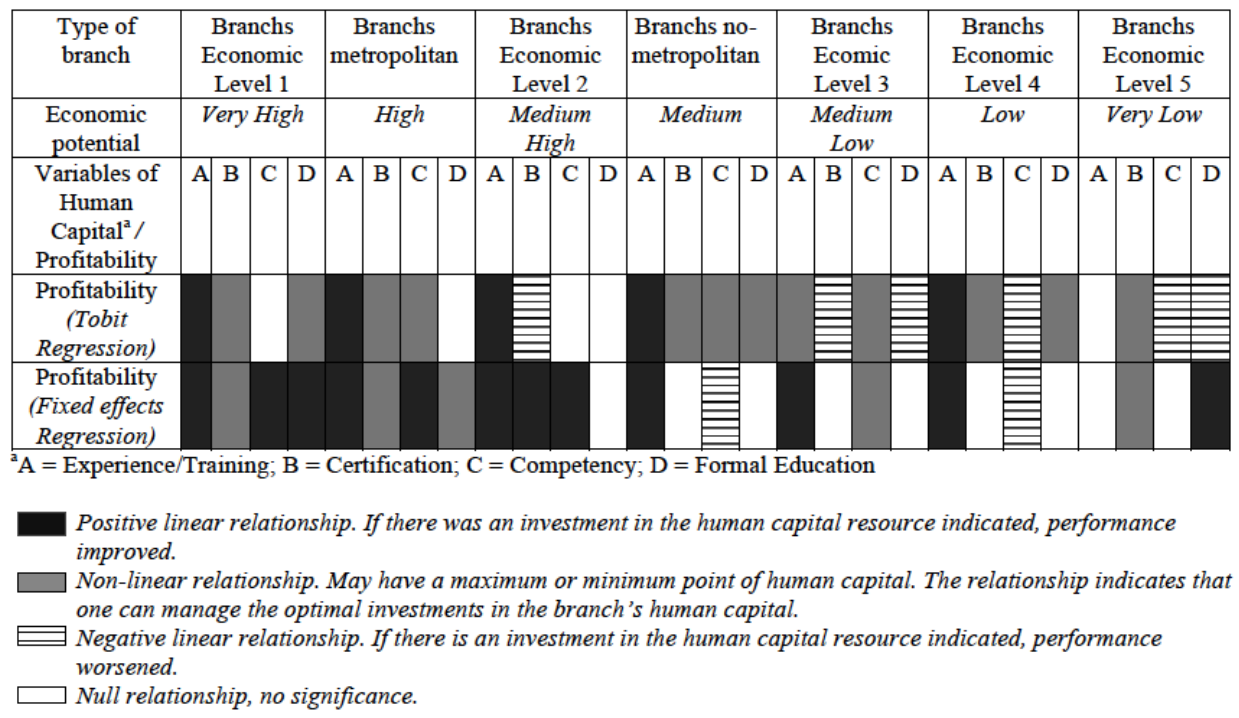

\subsection{The Importance of Context in the Relationship between Human Capital and Performance in the Credit Process}

An analysis was also conducted for the regressions between $\mathrm{HC}$ and the five dependent variables for the credit process (individual timely payments, corporate timely payments, advances to depositors, loans contracted, and credit limit record) separately for each of the seven economic clusters. The aim was to verify whether economic and regional differences interfere with the effectiveness of $\mathrm{HC}$ for performance in the credit process.

The classification of the branches by economic levels imposes a specific work organization and a particular customer base that impact the branches' internal processes and labor relations. Thus, this study aims to understand whether the dynamic of classifying branches by economic levels interferes with the Bank's performance in the credit process, an essential activity for any banking institution. The results obtained from these regressions are particularly surprising and help explain the nature of the Bank's human capital. To demonstrate the relevant phenomena, Table 5 summarizes the results of tobit panel regressions between HC variables and the dependent variables for credit process. Table 5 also include the relationships between HC and the dependent variable profitability to enable a comprehensive analysis of the question. The most important phenomena and impacts observed in Table 5 are discussed below. 
Table 5. Summary of the results of the tobit regressions, by branches level, in the relationships between human capital and dependent variables

\begin{tabular}{|c|c|c|c|c|c|c|c|c|c|c|c|c|c|c|c|c|c|c|c|c|c|c|}
\hline $\begin{array}{l}\text { Human Capital/ } \\
\text { Dependent Variables }\end{array}$ & \multicolumn{4}{|c|}{ Competency } & \multicolumn{6}{|c|}{ Certification } & \multicolumn{4}{|c|}{$\begin{array}{c}\text { Formal } \\
\text { Education }\end{array}$} & \multicolumn{4}{|c|}{$\begin{array}{l}\text { Experience/ } \\
\text { Training }\end{array}$} & \multicolumn{4}{|c|}{$\begin{array}{l}\text { Corporate } \\
\text { Educator }\end{array}$} \\
\hline Branches level $^{\mathrm{a}}$ & \begin{tabular}{l|l|l}
1 & 2
\end{tabular} & \begin{tabular}{l|l|}
3 & 4
\end{tabular} & & $\mathrm{NM}$ & 1 & $2 \mid 3$ & 4 & 51 & & $\mathrm{M}$ & \begin{tabular}{l|l|}
1 & 2
\end{tabular} & \begin{tabular}{|l|l|l|}
3 & 4 \\
\end{tabular} & \begin{tabular}{l|l|l|}
4 & 5 & $N$ \\
\end{tabular} & $\mathrm{M}$ & \begin{tabular}{|l|l|}
1 & 2 \\
\end{tabular} & 3 & & $5 \mathrm{NM}$ & \begin{tabular}{|l|l|l|} 
& 2 \\
\end{tabular} & \begin{tabular}{|l|l|l}
3 & 4
\end{tabular} & \begin{tabular}{|l|l|l|l}
5 & $N$ \\
\end{tabular} & $\mathrm{M}$ \\
\hline $\begin{array}{l}\text { Individual Timely } \\
\text { Payments }\end{array}$ & & & & & & & & & & & & & & & 目目 & & & 彗 & & & & \\
\hline $\begin{array}{l}\text { Corporate Timely } \\
\text { Payments }\end{array}$ & & & & & & E & & & & & & & & & & & & & & & & \\
\hline Advances to Depositor & & & & & & & & & & & & & & & 㫪 & & & & & & & \\
\hline Loans Contracted & & & & & & & & & & & & & & & & & & & & & & \\
\hline Credit Limit Record & & & & & & & & & & & & & & & & & & & & & & \\
\hline Profitability & & & & & & E & & & & & & 貝 & 貝 & & & & & & & & & \\
\hline
\end{tabular}

Positive linear relationship. If there was an investment in the human capital resource indicated, performance improved. Non-linear relationship. May have a maximum or minimum point of human capital. The relationship indicates that one can manage the optimal investments in the branch's human capital.

Negative linear relationship. If there is an investment in the human capital resource indicated, performance worsened. Null relationship, no significance.

a) Relative impacts of each HC resource on the Bank's performance - Table 5 enables numerous insights into the relative impact of each $\mathrm{HC}$ resource on performance in the credit process. A relevant example is the improved performance in the credit process for the Bank's main branches (Level 1, Level 2, and metropolitan). For this result to occur, it is necessary to increase the HC resources competency and certification for individual timely payments; the resources formal education, competency, and experienceltraining for corporate timely payments; the resource certification for advances to depositors; the resources certification and experience/training for loans contracted; and the resources competency, certification, and corporate educator for credit limit record. Profitability, in turn, increases in the Bank's main branches that invest in the experience/training binomial.

b) Effectiveness of HC resources on performance in the credit process - Table 5 shows the human capital resources in order of effectiveness on credit process performance. Competency and certification are the HC resources that best explain credit process performance. The predominance of black-filled cells signifies a positive linear relationship between these independent $\mathrm{HC}$ variables and most of the dependent variables analyzed for the credit process. Next in order of importance are formal education, experience/training, and corporate educator. The results shown in Table 5 allow the Bank to guide its direction, location, and intensity of investments in $\mathrm{HC}$ resources in the different branch clusters researched to obtain good overall performance in the credit process.

c) Temporal durability of HR practices and the importance of specific competences for corporate results Also in Table 5, it is interesting to observe that the two HC resources competency and certification, developed through the HR practices implemented most recently (2004 and 2005), are noticeably more effective in creating good performance in credit processes. Corporate educator, training, and valorization of experience are linked to older HR practices that were implemented in the 1960s and are seen as controversial HC resources and less effective at explaining this type of performance. Experience/training, which is very effective in creating profitability, is less effective at achieving performance in credit processes, except for corporate timely payments. This result shows that the effectiveness of certain $\mathrm{HC}$ variables can vary significantly within the company's work process. Another significant result is that the three main HC resources in terms of effectiveness (competency and certification for performance in the credit process and experience/training for profitability) are tied to the Bank's specific competences, confirming the findings of Grant (1996), Dutta et al. (2005), Kor and Mahoney (2005) and Crook et al. (2011).

d) Optimal set of HC resources for each type of performance desired by the Bank - Table 5 enables a visualization of the most appropriate set or "optimal set" of HC resources for each type of performance desired by the Bank. The set of HC resources will only be "optimal" if it attends to all, or at least a large majority, of the branch clusters to cover the Bank's service system. Performance in corporate timely performance, for example, is positively impacted by the resource competency in Levels 2, 3, 4, 5, no-metropolitan, and metropolitan branch clusters. This phenomenon does not occur in Level 1 branches. However, the resources experience/training and 
formal education have a positive linear impact on performance in corporate timely payments in the Level 1 cluster. Together, the three HC resources reach the complete set of bank branches in the organization and can be considered an "optimal set" of resources or the best set possible to achieve exceptional performance levels in corporate timely payments. Thus, the "optimal set" of $\mathrm{HC}$ for corporate timely payments is formed by competency, formal education, and experienceltraining. For individual timely payments, the optimal set of $\mathrm{HC}$ is formed by competency and certification. For advances to depositors, the optimal set consists of certification and formal education. For loans contracted, the set consists of competency, certification, and experience/training. For credit limit record, in turn, the ideal set is competency, certification, and corporate educator. Last, to reach good levels of profitability, the set of $\mathrm{HC}$ resources appears to be limited to experience/training. The combination of the most appropriate $\mathrm{HC}$ resources for each type of performance is not the same, indicating that the optimal resource(s) may be different within the same company, depending on the type of performance desired. The differences observed between the optimal sets of HC resources for each type of desired performance project means that an $\mathrm{HC}$ resource must be contextualized to the work process because it needs to adhere to the specificities to which it is linked.

\subsection{Relative Impact of the Workforce and Turnover on Profitability and Credit Process Performance by Branch Level}

Table 6 shows a summary of the regression results for the relationships between control variables and dependent variables for the credit process, and control variables and the dependent variable profitability, both by branch level. Table 6 shows that high turnover can hinder performance in terms of profitability in most branches (Levels 1, 3, 5, no-metropolitan, and metropolitan). With regard to the size of the workforce, smaller teams appear to have a more positive relationship with profitability, unlike what one might expect. The predominance of cells filled with horizontal lines indicates that a smaller workforce can positively impact profitability. It is noteworthy that for the Level 1 branches, which are critical to the overall performance of the organization studied, this logic does not apply.

Table 6. Summary of the results of the tobit regressions, by branches level, in the relationships between control variables and dependent variables

\begin{tabular}{|c|c|c|c|c|c|c|c|c|c|c|c|c|c|c|}
\hline \multirow{2}{*}{$\begin{array}{l}\text { Control Variables/ Dependent Variables } \\
\text { Branches Level }^{\mathrm{a}}\end{array}$} & \multicolumn{7}{|c|}{ Workforce } & \multicolumn{7}{|c|}{ Turnover } \\
\hline & 1 & 2 & 3 & 4 & 5 & $\mathrm{~N}$ & M & 1 & 2 & 3 & 4 & 5 & $\mathrm{~N}$ & M \\
\hline \multicolumn{15}{|l|}{ Corporate Timely Payments } \\
\hline \multicolumn{15}{|l|}{ Individual Timely Payments } \\
\hline \multicolumn{15}{|l|}{ Advances to Depositors } \\
\hline \multicolumn{15}{|l|}{ Credit Limit Records } \\
\hline \multicolumn{15}{|l|}{ Loans Contrated } \\
\hline Profitability & & & & & & & & & & & & & & \\
\hline
\end{tabular}

Note. ${ }^{\mathrm{a}}$ Level branches 1 to 5 (Economic potential of the area); $\mathrm{N}$ - no-metropolitan area; $\mathrm{M}$ - metropolitan area.

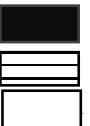

Positive linear relationship

Negative linear relationship

relationship, no significance

When analyzing the relationships between the control variables (workforce and turnover) and the dependent variables on the credit process, several phenomena are observed in Table 6 . The first is the importance of the size of the workforce to achieve better performance in individual timely payments. A large workforce may favor individual timely payments in the Bank's main branches (Levels 1,2, and metropolitan). Turnover is perceived as a problem for individual timely payments. High levels of turnover generate some level of individual default. Corporate timely payments are little affected by the control variables and are more affected by the $\mathrm{HC}$ variables. In general, the results indicate that the control variable turnover appears to be a specific problem for the performance variable individual timely payments but does not have a significant impact on the other four dependent variables in the credit process.

The dependent variables credit limit record and loans contracted are also sensitive to the size of the workforce. The predominance of the color black in the relationships between the control variable workforce and the two operational performance variables confirms this sensitivity. In most of the branch clusters studied, a larger workforce had a positive linear impact on the dependent variables credit limit record and loans contracted. The likely explanation is that work processes tied to these variables are characterized by intensive labor. The surprise 
is due to the negative linear relationship between the control variable size of the workforce and the credit process performance advances to depositors. The explanation from some specialists in this type of operation is that the volume of operations for advances to depositors is naturally increasing in the larger branches, although it was not possible to access data that confirmed this assertion. The last two columns in Table 3 depict the impact of turnover and workforce on all of the Bank's branches combined.

\section{Discussion}

The results shown in this study confirm the findings of empirical studies on the impact of systems of HR practices on firm performance with respect to three key questions: 1) the positive impact of HC or the HRM practices system on the Bank's performance; 2) the importance of specific competences for the Bank's performance; and 3) the negative impact of turnover on the Bank's performance.

Regarding the specific contributions to the literature on HC in companies, three main contributions stand out: 1) this study overcomes the fallacies and potential biases of empirical studies on $\mathrm{HC}$ in organizations, as described by Ployhart and Moliterno (2011);2) the study provides empirical confirmation that the HC inventory is an effective instrument to study the emergence and performance of this capital in the firm's environment; and 3) the study confirms the role of the local economic context on the relationship between $\mathrm{HC}$ and organizational performance.

\subsection{This Study Overcomes the Fallacies and Potential Biases of Empirical Studies on Human Capital in Organizations}

"The more human capital, the better". The first fallacy overcome is the approach "more is better", or the more human capital, the better an organization's performance. The assumption is that there are not decreasing returns for talent. The results of this study show that the relationship between human capital and performance in profitability and credit process do not necessary function in that manner. At least four elements were found that contradict the approach "the more human capital, the better". First, non-linear curves were found, suggesting that in certain situations there are optimal levels of HC in companies to reach certain results. Second, it was found that the positive linear curves are more common when they are tied to specific competences. Third, in a few cases, some paradoxically negative linear relationships were found, which indicate a costly and incomplete $\mathrm{HC}$ resource. Fourth, the effectiveness of HC may depend on the external context;

"Some KSAOs are always valuable". The finding described in item above, introduces an important method to evaluate what should be included in the ideal HC (diversity and levels of resources). One can find an optimal set and another non-optimal set of $\mathrm{HC}$ resources for each type of performance desired by the firm, which indicates that some KSAOs are not always valuable, as noted by Ployhart and Moliterno (2011). Moreover, the study determined that developing corporate $\mathrm{HC}$ in economically unfavorable contexts, for example, may be valuable for the local community as social responsibility actions but are not necessarily valuable for the company from an economic point of view;

"All employees in a company show identical indicators for human capital". Another fallacy overcome in this study is the assumption that generic measures of a company's HC correctly represent the KSAOs of the workers and that all workers in a company show identical indicators for HC. The data collected from the Bank's inventory of human capital show the variance in HC between the branches, which is reflected in the branches' internal environments. From the econometric analyses carried out on the impact of HC on the Bank's performance, it can be inferred that a specific, balanced set of KSAOs in each branch form performance-promoting HC. Rather, to be effective, the Bank's HC needs to be heterogeneous because it is tied to the types of performance intended for each work unit. Therefore, it can be stated that $\mathrm{HC}$ emerges when it is effective to achieve performance, and three conditions must be met: 1) the optimal sets of $\mathrm{HC}$ resources must be identified for each type of desired performance (see Table 5). It is worth noting that defining the optimal sets of $\mathrm{HC}$ resources for each branch is the same as setting the level of heterogeneity of HC by the various units and processes in the organization; 2) the local economic context that favors the emergence of that HC must be evaluated (see Tables 4 and 5); and 3) it must be determined whether there is a gap in HC in the team and, if there is, the HRM practices that best develop this optimal set of resources must be applied. Thus, the formation of specific or "ideal" HC is put in motion for the desired overall performance. From this logic, it can be inferred that the same company needs relatively different sets of KSAOs to attend to the different productive units and obtain several types of desired performance, causing employees and teams to have different types of KSAOs that are oriented toward specific challenges and performances. In fact, it does not appear correct to treat the HC of companies as a homogeneous phenomenon;

"Ignore the non-cognitive profile of the employee". The so-called non-cognitive employee profile was not 
ignored in this study, although it is very difficult to measure. The results from analyzing the impact of the 360-degree competency assessment (HC resource competency) on the Bank's performance show that this HC resource is an important predictor of corporate performance. It is also one of the most effective HC resources in the whole process of analysis. It is noteworthy that the resource competency includes aspects of the employee's non-cognitive profile, such as several types of the technical and behavioral competencies under evaluation;

"Research based on subjective studies and managerial self-reports". Last, this study's form of research moved away from the so-called subjective studies (Ployhart and Moliterno, 2011) and managerial self-reports (Hatch and Dyer, 2004; Wiklund and Shepherd, 2003). This study is a population-based inventory of HC in a large Bank and its thousands of comparable production units, totaling 55,550 employees.

\subsection{The Study Provides Empirical Confirmation That the HC Inventory Is an Effective Instrument to Study the Emergence and Performance of This Capital in the Firm's Environment}

This finding is linked to the theoretical concept that human capital is a mediator in the relationship between HR practices and performance (Batt, 2002; Jiang et al., 2012; Marimuthu et al., 2009; Ramsey et al., 2000; Takeuchi et al., 2007; Yound \& Snell, 2004). By knowing a company's HC, the type or levels of performance to be expected are also known, as are the specific HR practices that will contribute to an effective formation of HC. Thus, mapping the Bank's HC allows one to understand: 1) the most or least effective HR practices to achieve the various types and levels of performance desired by the Bank as well as the system of high-performance HR practices (see the last column of Table 1, where the relative effectiveness of the Bank's HR practices is shown); 2) the impact or effectiveness of the various $H C$ resources on the different types of performance analyzed, enabling the organization to determine its investments in human capital according to its relative effectiveness (again, see Table 1, fourth column); 3) the impact of specific competences and generic competences on the Bank's performance (Hypothesis 6 accepted); 4) the optimal sets of HC resources for each type of operational performance. The results revealed that there are objective differences in the optimal sets of HC resources depending on the performance desired, which assumes that heterogeneous human capital is contextualized in the work process. This result suggests that corporate $\mathrm{HC}$ should adhere to the specificities and challenges to which it is tied. For example, the regressions performed in this study suggest that training and experience constitute the optimal set of $\mathrm{HC}$ to achieve high levels of profitability, while certification and competency are parts of the most effective set of resources to reach individual timely payments. This and other findings not only enable the improvement of HR management practices in the company but also suggest a revelation about the property or character of $\mathrm{HC}$ in organizations: depending on the desired goal, corporate $\mathrm{HC}$ is not always valuable. Thus, a positive linear relationship cannot be expected between performance and all of the HC resources developed by the company. In fact, one must determine which HC resources are most or least effective for each type of performance and how the relationship curve is established. Therefore, $\mathrm{HC}$ is dynamic and contextualized in the work process because it needs to adhere to the specificities to which it is linked. In other words, in terms of level and diversity, $\mathrm{HC}$ appears to be specific for each type of performance; 5) The temporal durability of HR practices for certain types of operational performance. The Bank's two most recent $\mathrm{HC}$ resources (competency and certification) are notably more effective, particularly in regard to operational performance in the credit process. Conversely, the classic, or oldest, $\mathrm{HC}$ resources, such as training and valorization of experience, are almost entirely only effective at generating profitability. The first finding is that some HR practices that were effective in the past for all of the organizational goals and challenges are currently limited in terms of effectiveness to specific challenges or types of performance. This phenomenon is what appears to have happened with the practice of corporate training, a development professional methodology that is most likely less appropriate for the demands of certain standardized work processes and more suitable for activities or performances that demand systemic competencies. The second finding is that contemporary HR practices, such as the 360-degree competency assessment and the systems for certification of knowledge, apparently respond well to systematic and standardized processes. Such processes are frequent activities that need to coexist with the more sophisticated control processes, as is the case with banks. These considerations suggest that the HC inventory is a more advantageous method of empirical study than the classical method based on questionnaires and interviews because it enables a practical understanding of the emergence and performance of $\mathrm{HC}$ in companies.

\section{Conclusion}

This study sought to understand two fundamental and inter-related mechanisms regarding HC in the Bank studied: on the one hand the emergence, which describes the HR practices that create the optimal sets of HC resources to sustain the company's performance; on the other hand, the effectiveness or relative performance of each HC dimension addressed. The results show that effective HC mainly emerges because of the creation of an 
optimal set of $\mathrm{HC}$ resources to achieve each type of desired performance and the development of specific competences tied to the Bank's processes and businesses. Thus, effective HC should occur abundantly and permanently, but in a directed manner. The use of a synergistically articulated system for HR practices that identifies, maintains, rewards, encourages, and especially develops both the optimal sets of HC resources and specific competences is vital for the emergence of effective HC in the Bank. The development of generic competences that focus on higher education and graduate education should be understood as a support or a preliminary basis to improve specific competences and not as an autonomous or main activity in the professional development of a bank's employees.

If there are optimal sets of HC in a company, then non-optimal sets must also exist, which indicates that not all KSAOs are always valuable. These elements enable the establishment of what can be called the character or properties of a corporation's HC. First, HC should be dynamic and heterogeneous, which are necessary conditions for it to effectively respond to the diversity of contexts and demands, whether by virtue of exogenous forces, such as the local economic context, or due to the magnitude of the goals established in the corporate strategy. Second, HC must be specific for the challenge or type of performance desired. Third, as a result of the first two phenomena, $\mathrm{HC}$ is not always valuable, depending on the purpose for which it is intended.

Turnover, the size of the workforce in the branches, and the impact of the external economic context were examined in this study. The results show that high turnover is a problem for the emergence of $\mathrm{HC}$ in the individual credit process (individual timely payments) and also for profitability. An appropriately sized workforce is vital for the emergence of effective HC in the Bank. Some processes require a larger workforce to obtain better performance; others require a smaller and most likely more permanent and qualified workforce. Another important phenomenon that can counteract the effectiveness of the Bank's $\mathrm{HC}$ is the external environment, or the economic condition of the region where the branch is located. Favorable economic conditions may enhance the effectiveness of a branch's HC; unfavorable economic conditions may counteract the emergence of effective HC.

Regarding the levels of effectiveness for the HC in the Bank studied, the results show that training and experience are critical to achieving optimal levels of profitability. Conversely, competency, resulting from the 360-degree competency assessment, and certifications of specific knowledge generally appear to be decisive in achieving better performance levels in credit processes.

Subject to these conditions, it can be stated that effective HC in the Bank emerged, producing high overall performance.

Last, it is important to consider the limitations of this study. Limiting the scope of analysis to a single company, although a large one with thousands of branches and employees, prevents a generalization of the results. More studies should be conducted on similar companies to develop a theory of $\mathrm{HC}$ for the service industry, as relevant in the knowledge society.

\section{References}

Amemiya, T. (1984). Tobit models: A survey. Journal of Econometrics, 24, 3-61. https://doi.org/10.1016/0304-4076(84)90074-5

Argyris, C., \& Schon, D. A. (1978). Organizational learning: A theory of action perspective. Addison Wesley: Reading, Mass.

Baker, G., Gibbons, R., \& Murphy, K. J. (1994). Subjective performance measures in optimal incentive contracts. Quarterly Journal of Economics, 108(8), 1125-1256. https://doi.org/10.2307/2118358

Barney, J. (1991). Firm resources and sustained competitive advantage. Journal of Management, 17(1), 99-120. https://doi.org/10.1177/014920639101700108

Barney, J. (1996). The resource-based theory of the firm. Organizational Science, 7(5), 469. https://doi.org/10.1287/orsc.7.5.469

Batt, R. (2002). Managing customer services: Human resource practices, quit rates, and sales growth. Academy of Management Journal, 45, 587-597. https://doi.org/10.2307/3069383

Becker, G. S. (1964). Human capital (3rd ed.). University of Chicago Press: Chicago.

Bloom, N., \& Reenen, V. J. (2010). Human resource management and productivity. CEP Discussion Paper n. 982. London: London School of Economics and Political Science, Centre for Economic Performance. https://doi.org/10.3386/w16019

Brandão, H. P. (2009). Aprendizagem, contexto, competência e desempenho: Um estudo multinível. Unpublished 
doctoral dissertation, Universidade de Brasília, Brasília.

Brandão, H. P. et al. (2008). Gestão de desempenho por competências: Integrando a avaliação 360 graus, o balanced scorecard e a gestão por competências. Revista de Administração Pública, 42(5), 875-898. https://doi.org/10.1590/S0034-76122008000500004

Carbone, P. P., Brandão, H. P., Diniz, J. B., \& Vilhena, R. P. (2009). Gestão por competência e gestão do conhecimento (3nd ed.). Fundação Getúlio Vargas: Rio de Janeiro.

Carmeli, A. (2004). Strategic human capital and the performance of public sector organizations. Scandinavian Journal of Management, 20, 375-392. https://doi.org/10.1016/j.scaman.2003.11.003

Cart, B., \& Toutin, M. H. (1998). La production d'adaptabilité: Les modalités de construction de l'expérience professionnelle. In Stankiewicz F. (Ed.), Travail compétences et adaptabilité (pp. 137-157). L'Harmattan: Paris.

Chi, T. (1994). Trading in strategic resources: Necessary conditions, transaction cost problems, and choice of exchange structure. Strategic Management Journal, 15, 271-290. https://doi.org/10.1002/smj.4250150403

Coff, R. W. (2002). Human capital, shared expertise, and the likelihood of impasse in corporate acquisitions. Journal of Management, 28, 107-128. https://doi.org/10.1177/014920630202800107

Cronbach, L. J. (1949). Essentials of psychological testing. Harper: New York.

Crook, T. R., Todd, S. Y., Combs, J. G., Woehr, D. J., \& Ketchen, D. J. (2011). Does human capital matter? A meta-analysis of the relationship between human capital and firm performance. Journal of Applied Psychology, 96(3), 443-456. https://doi.org/10.1037/a0022147

Cutcher-Gershenfeld, J. (1991). The impact in economic performance of a transformation in industrial relations. Industrial and Labor Relations Review, 44, 241-260. https://doi.org/10.1177/001979399104400204

Delaney, J., \& Huselid, M. (1996). The impact of human resources management practices on perceptions of organizational performance. Academy of Management Journal, 39(4), 949-969. https://doi.org/10.2307/256718

Delery, J. E. (1998). Issues of fit in strategic human resource management: implications for research. Human Resource Management Review, 8(3), 289-309. https://doi.org/10.1016/S1053-4822(98)90006-7

Dierickx, I., \& Cool, K. (1989). Asset stock accumulation and sustainability of competitive advantage. Management Science, 35, 1504-1511. https://doi.org/10.1287/mnsc.35.12.1504

Dutta, S., Narasimhan, O., \& Rajiv, S. (2005). Conceptualizing and measuring capabilities: Methodology and empirical application. Strategic Management Journal, 26, 277-285. https://doi.org/10.1002/smj.442

Edvinsson, L., \& Malone, M. S. (1998). Intellectual capital. Piatkus: London.

Edwards, M., \& Ewen, A. J. (1996). $360^{\circ}$ feedback: the powerful new model for employee assessment and performance improvement. American Management Association: New York.

Gilbert, T. F. (1978). Human competence: Engineering worthy performance. McGraw-Hill Book Company: New York.

Grant, R. M. (1991). The resource-based theory of competitive advantage: implications for strategy formulation. California Management Review, 33(3), 114-135. https://doi.org/10.2307/41166664

Grant, R. M. (1996). Prospering in dynamically-competitive environments: Organizational capability as knowledge integration. Organization Science, 7, 375-387. https://doi.org/10.1287/orsc.7.4.375

Greene, W. H. (2003). Econometric analysis (5nd ed). Prentice Hall: New Jersey.

Hatch, W. N., \& Dyer, H. J. (2004). Human capital and learning as a source of sustainable competitive advantage. Strategic Management Journal, 25, 1155-1178. https://doi.org/10.1002/smj.421

Holmstrom, B., \& Milgrom, P. (1994). The firm as an incentive system. American Economic Review, 84(4), 972-991.

Hoskisson, R. E., Hitt, M. A., Wan, W. P., \& Yiu, D. (1999). Theory and research in strategic management: Swings of a pendulum. Strategic Management Journal, 25(3), 417-456. https://doi.org/10.1177/014920639902500307

Huselid, M. A. (1993). Essays on human resource management practices, turnover, productivity, and firm performance. Unpublished Doctoral Dissertation, State University of New York at Buffalo: New York. 
Huselid, M. A. (1995). The impact of human resource management on turnover, productivity, and corporate financial performance. Academy of Management Journal, 38, 635-670. https://doi.org/10.2307/256741

Huselid, M. A., \& Becker, B. E. (1994). The strategic impact of human resources: Results from a panel study. Working paper, Rutgers University: New Brunswick, NJ.

Ichniowski, C., Shaw, K., \& Prennushi, G. (1997). The effects of human resource management practices on productivity: A study of steel finishing lines. The American Economic Review, 87(3), 291-313.

Iddekinge, C. H. et al. (2009). Effects of selection and training on unit-level performance over time: A latent growth modeling approach. Journal of Applied Psychology, 94(4), 829-843. https://doi.org/10.1037/a0014453

Ienaga, C. H. (1998). Competence-based management. Seminário Executivo, Dextron Consultoria Empresarial: São Paulo.

Jackson, S. E., \& Schuler, R. S. (1995). Understanding human resource management in the context of organizations and their environments. In M. R. Rosenzweig and L.W.Porter (Eds.), Annual Review of Psychology, 46, 237-264. Annual Reviews: Palo Alto, CA. https://doi.org/10.1146/annurev.ps.46.020195.001321

Jiang, K. et al. (2012). Clarifying the construct of human resource systems: Relating human resource management to employee performance. Human Resource Management Review 22, 73-85. https://doi.org/10.1016/j.hrmr.2011.11.005

Kandel, E., \& Lazear, E. (1992). Peer pressure and partnerships. Journal of Political Economy, 100(4), 801-17. https://doi.org/10.1086/261840

Kaplan, R., \& Norton, D. (2004). Mapas estratégicos: Convertendo ativos intangíveis em resultados tangíveis. Elsevier: Rio de Janeiro.

Keats, B. W., \& Hitt, M. A. (1988). A causal model of linkages among environmental dimensions, macro organizational characteristics, and performance. Academy of Management Journal, 31(3), 570-598. https://doi.org/10.2307/256460

Kogut, B., \& Zander, U. (1992). Knowledge of the firm, combinative capabilities, and the replication of technology. Organization Science, 3, 383-397. https://doi.org/10.1287/orsc.3.3.383

Kor, Y., \& Mahoney, J. T. (2005). How dynamics, management, and governance of resource deployments influence firm-level performance. Strategic Management Journal, 26, 489-496. https://doi.org/10.1002/smj.459

Kozlowski, S. W. J., \& Klein, K. J. (2000). A multilevel approach to theory and research in organizations: Contextual, temporal, and emergent processes. In K. J. Klein, \& S. W. J. Kozlowski (Eds.), Multilevel theory, research, and methods in organizations: Foundations, extensions, and new directions (pp. 3-90). Jossey-Bass: San Francisco.

Le Boterf, G. (1999). Competénce et navigation professionnelle. Éditions d'Organisation: Paris.

Lippman, S. A., \& Rumelt, R. P. (1982). Uncertain imitability: An analysis of interfirm differences in efficiency under competition. Bell Journal of Economics, 13, 418-438. https://doi.org/10.2307/3003464

Lubinski, D. (2000). Scientific and social significance of assessing individual differences: Sinking shafts at a few critical points. Annual Review of Psychology, 51, 405-444. https://doi.org/10.1146/annurev.psych.51.1.405

MacDuffie, J. P. (1995). Human resource bundles and manufacturing performance: Flexible production systems in the world auto industry. Industrial and Labor Relations Review, 48, 197-221. https://doi.org/10.1177/001979399504800201

Marimuthu, M., Arokiasamy, L., \& Ismail, M. (2009). Human capital development and its impact on firm performance: Evidence from developmental economics. The Journal of International Social Research, 2(8).

Milgrom, P., \& Roberts, J. (1990). The economics of modem manufacturing. American Economic Review, 80(3), $511-28$.

Mincer, J. (1958). Investment in human capital and personal income distribution. The Journal of Political Economy, LXVI(4), 281-302. https://doi.org/10.1086/258055

Nonaka, I., \& Takeuchi, H. (1997). Criação de conhecimento na empresa: Como as empresas japonesas geram a dinâmica da inovação. Campus: Rio de Janeiro. 
Normann, R. (1984). Service management: Strategy and leadership in service businesses. Wiley: Chichester, U.K.

Penrose, E. T. (1959). The theory of the growth of the firm. Wiley: New York.

Ployhart, R., \& Moliterno, T. (2011). Emergence of the human capital resource: A multilevel model. Academy of Management Review, 36(1), 127-150. https://doi.org/10.5465/amr.2009.0318

Porter, M. E. (1989). Vantagem competitiva: Criando e sustentando um desempenho superior. Campus: Rio de Janeiro.

Prahalad, C. K., \& Hamel, G. (1990). The core competence of the corporation. Harvard Business Review, 68(3), 79-91.

Ramsey, H., Scholarios, D., \& Harley, B. (2000). Employees and high performance work systems: Testing inside the black box. British Journal of Industrial Relations, 38, 501-531. https://doi.org/10.1111/1467-8543.00178

Ray, G., Barney, J. B., \& Muhanna, W. A. (2004). Capabilities, business processes, and competitive advantage: Choosing the dependent variable in empirical tests of the resource-based view. Strategic Management Journal, 25, 23-37. https://doi.org/10.1002/smj.366

Razin, E. (1998). Fiscal disparities among local authorities in Israel 1972-1995. The Floersheimer Institute for Policy Studies: Jerusalem.

Razin, E. (1999). Fiscal disparities between small and large municipalities in Israel. The Floersheimer Institute for Policy Studies: Jerusalem.

Richard, P., De6nney, T., Yip, G., \& Johnson, G. (2009). Measuring organizational performance: Towards methodological best practice. Journal of Management, 35, 718-804. https://doi.org/10.1177/0149206308330560

Rumelt, R. (1984). Toward a strategic theory of the firm. In R. Lamb (Ed.), Competitive strategic management (pp. 556-570). Prentice-Hall: Englewood Cliffs; NJ.

Sanchez, R., \& Heene, A. (1997). Competence-based strategic management: Concepts and issues for theory, research, and practice. In A. Heene, \& R. Sanchez (Eds.), Competence-based strategic management (pp. 3-42). SMS Series. John Wiley and Sons: Chichester.

Senge, P. (2003). A quinta disciplina: A arte e prática da organização de aprendizagem. Best Seller: São Paulo.

Skaggs, B., \& Youndt, M. (2004). Strategic positioning, human capital, and performance in service organizations: A customer interaction approach. Strategic Management Journal, 25, 85-99. https://doi.org/10.1002/smj.365

Stewart, T. A. (1998). Capital intelectual. Campus: Rio de Janeiro.

Sveiby, K. (1998). A nova riqueza das organizações: Gerenciando e avaliando patrimônios de conhecimento. Campus: Rio de Janeiro.

Takeuchi, R., Lepak, D., Wang, H., \& Takeuchi, K. (2007). An empirical examination of the mechanisms mediating between high-performance work systems and the performance of japanese organizations. Journal of Applied Psychology, 92(4), 1069-1083. https://doi.org/10.1037/0021-9010.92.4.1069

Von Bertalanffy, L. (1950). The theory of open systems in physics and biology. Science, 11, 23-29. https://doi.org/10.1126/science.111.2872.23

Wernerfelt, B. (1984). A resource-based view of the firm. Strategic Management Journal, 5, 171-180. https://doi.org/10.1002/smj.4250050207

Whiddett, S., \& Hollyforde, S. (1999). The competencies handbook. Institute of Personnel and Development: London.

Wiklund, J., \& Shepherd, D. (2003). Knowledge-based resources, entrepreneurial orientation, and the performance of small and medium-sized businesses. Strategic Management Journal, 24, 1307-1314. https://doi.org/10.1002/smj.360

Wooldridge, J. M. (2002). Econometric analysis of cross section and painel data. Mass: MIT Press: Cambridge.

Wright, P. M., \& Boswell, R.W. (2002). Desegregating HRM: A review and synthesis of micro and macro human resource management research. Journal of Management, 28(3), 247-276. 
https://doi.org/10.1177/014920630202800302

Wright, P. M., Dunford, B. B., \& Snell, S. A. (2001). Human resources and the resource based view of the firm. Journal of Management, 27, 701-721. https://doi.org/10.1177/014920630102700607

Wright, P. M., McMahan, G. C., \& McWilliams, A. (1994). Human resources and sustained competitive advantage: A resource-based perspective. International Journal of Human Resource Management, 5(2), 301-326. https://doi.org/10.1080/09585199400000020

Youndt, M., \& Snell, S. (2004). Human resource configurations, intellectual capital, and organizational performance. Journal of Managerial Issues, 16(3), 337-360.

Youndt, M., Snell, S., Dean, J. W. Jr., \& Lepak, D. (1996). Human resource management, manufacturing strategy, and firm performance. Academy of Management. Journal, 39, 836-866. https://doi.org/10.2307/256714

Zarifian, P. (1999). Objectif compétence: Pour une nouvelle logique. Editions Liaisons: Paris.

\section{Copyrights}

Copyright for this article is retained by the author(s), with first publication rights granted to the journal.

This is an open-access article distributed under the terms and conditions of the Creative Commons Attribution license (http://creativecommons.org/licenses/by/4.0/). 